Special theme section: Eisenstein, Bogdanov, and the organization of culture

\title{
Sergei Eisenstein in the Proletkult
}

\author{
JOHN BIGGART \\ independent scholar, United Kingdom; email: ramishvili@protonmail.com \\ OKSANA BULGAKOWA \\ Johannes Guttenberg Universität; e-mail: Bulgakowa@uni-mainz.de \\ Commentary by IAN CHRISTIE
}

\begin{abstract}
Keywords: Lunacharskiy, Lenin, Meyerhold, Pletnëv, Strike, Proletkult Theatre
This article examines some of the theoretical issues that exercised Sergei Eisenstein during the years 1920-1924 when he worked in the Russian Proletarian Cultural-Educational Organization (Proletkult), of which Aleksandr Bogdanov was one of the founders. We ask how far Eisenstein was influenced by Marxism in general and by the ideas of Bogdanov in particular, and explain his exit from the Proletkult in terms of the unacceptability of his theory and practice of theatre and film to the Chairman of the Proletkult, Valeriyan Pletnëv. During these years the Agitprop Department of the Central Committee of the Communist Party, at Lenin's behest, was taking steps to reduce the scope of activities of the Proletkult, discredit Bogdanov as a thinker, and exclude him from politics.
\end{abstract}

"There are two specific trends that I physically cannot stand: first, art prolétaire quand-même and second, the 'Stanislavskiy system' ..."'

"A polemic. An unequal combat between an individual and an organization (it was yet to be dethroned for its claims to have a monopoly on proletarian culture). At any moment, the matter could turn into 'persecution'... I was threatened with unpleasant things by the Proletkult."2

\section{Science in the service of ideology ${ }^{3}$}

The years during which Eisenstein worked under the aegis of the Proletkult were years during which he developed his "theory of attractions" and applied the theory in his earliest theatrical and first film productions. ${ }^{4}$ In "Montage of Attractions" (1923) he described his understanding of the theatrical

\footnotetext{
Eisenstein, letter to his mother, 4 January 1921. Bulgakowa 2001a: 24 Eisenstein 1997: 111-113; Taylor and Powell 1995: 147-148.

In this paper, individual terms used by Eisenstein or other writers, as well as quotations from their works, are indicated by double inverted commas.

4 On the evolution of Eisenstein's theories, see Clark 1995: 179-181; Bulgakowa 2001c: 38-51; 2014: 423-448 and 2022: Chapter 3 . For accounts of Eisenstein's work in the Proletkult, see Hielscher 1973 and Mally 1990: 240-241.
} 
programme of the Proletkult as follows: "the moulding of the audience in a desired direction (or mood) is the task of every utilitarian theatre (agitation, advertising, health education, etc." An "attraction" was:

"... an aggressive moment in theatre, i.e., any element of it that subjects the audience to emotional or psychological influence, verified by experience and mathematically calculated to produce specific emotional shocks in the spectator in their proper order within the whole. These shocks provide the only opportunity of perceiving the ideological aspect of what is being shown, the final ideological conclusion ..." (Taylor 2010: 34). ${ }^{5}$

In "Montage of Film Attractions" (1924), Eisenstein argued that this theory was also applicable to film, which, he claimed, shared with the theatre the purpose of "influencing the audience in a desired direction through a series of calculated pressures on its psyché" (Taylor 2010: 39). ${ }^{6}$ Indeed, "... there is, or rather should be, no cinema other than agit-cinema. The method of agitation through spectacle consists in the creation of a new chain of conditioned reflexes by associating selected phenomena with the unconditioned reflexes they produce (through the appropriate methods)" (Taylor 2010: 45).

The sources that Eisenstein drew upon for his understanding of reflexology were Vladimir Bekhterev (1857-1927) ${ }^{7}$ and Ivan Pavlov (1849-1936). ${ }^{8}$ He had recourse to other science in seeking to ensure that the movements of his "model actor" (naturshchik) would achieve the necessary "affect": the "whole process of the actor's movement [should be] organized with the aim of facilitating the imitative capacities of the audience" (Taylor 2010: 50). Movements should be selected "from the versions that are most characteristic of real circumstances". This selection was not to be made from the standard repertoire for associating gestures with emotions (as in mime); nor was the actor to 'enter into' the state of mind of a character (Taylor 2010: 50). ${ }^{9}$ Rather, movement should be broken down into its "pseudo-primitive primary component elements for the audience". These "neutral elements" would then be assembled and coordinated into a temporal schema by the actor and the director. The objective should be to achieve not the superficial imitation of a real action but an "organic representation that emerges through the appropriate mechanical schema and a real achievement of the motor process of the phenomenon being depicted" (Taylor 2010: 50). Such a "montage (assembly) of movements that are purely organic in themselves ... will involve the audience to the maximum degree in imitation and, through the emotional effect of this, in the corresponding ideological treatment ... We see that the methods of processing the audience do not differ in the mechanics of their realization from other forms of work movement ..." (Taylor 2010: 56.)

During the years 1921-1922, when he was working within the Proletkult, Eisenstein was also attending the "theatrical technical school" of Vsevolod Meyerhold where lectures on biomechanics were delivered by Nikolay Bernstein, and it is clear that his interest in the physiology and psychology of human movement originated or further developed at this time (Hoover 1974: Bulgakowa $2001 \mathrm{a}$ : 26; Bulgakowa 2014: 427; Braun 1995: 172-177). In "Montage of film attractions" (1924) he claimed to be making his own contribution in this field: "The norms of organicism ... for motor processes have been established partly by French and German theoreticians of movements (investigating kinetics

5 Yurenev, citing S. Yutkevich, notes that Eisenstein seized upon the term attraktion at a time when he had a special interest in pantomime. The term can also refer to a circus act or carnival amusement. In 1925 Eisenstein spoke of the "role of circus and sport in the renewal of acting skills". See "The problem of the materialist approach to form" in Taylor 2010: 60; and on the affinities between circus and theatre in the early 1920s, Yurenev 1985: 51, 58-59.

6 Emphasis in original.

7 For Eisenstein's reference to Bekhterev, see "Montage of Film Attractions", in Taylor 2010: 49 and, for his use of the term 'reflexology', "The method of making a workers' film" (August 1925), in Taylor 2010: 68. On Bekhterev's influence on Eisenstein's thinking see Olenina 2020, 195-235.

8 Pavlov is mentioned in "Through the Revolution to Art: Through Art to the Revolution" (1933) in Taylor 2010;243. Here, Eisenstein also mentions the influence of Freud.

9 In 1926 Eisenstein declared that "My artistic principle was, therefore, and still is, not intuitive creativity, but the rational constructive composition of effective elements; the most important thing is that the effect must be calculated and analysed in advance". Battleship Potemkin "had nothing to do with Stanislavskiy and the [Moscow] Art Theatre". See the translation of "Sergej Eisenstein uber Sergej Eisenstein - den Potemkin regisseur", Berliner Tageblatt, 7 June 1926, in Taylor 2010: 75-76. 
in order to establish motor primitives) and partly by me (kinetics in its application to complex expressive movements and the dynamics of both) ... in my laboratory work in the Proletkult Theatre" (Taylor 2010: 51). ${ }^{10}$ He goes on to mention the work of specialists in pathology (Hermann Nothnagel, 1841-1905); neurology and physiology (Guillaume-Benjamin-Armand Duchenne de Boulogne, 1806-1875); eurythmics (Émile Jaques-Dalcroze, 1865-1950); rhythmic gymnastics (Rudolphe Bode, 1881-1970); hygiene and physical exercize (Ferdinand Hueppe, 1852-1938); and expressive movement (Hermann Krukenberg, 1863-1895; Ludwig Klages, 1872-1956) (Taylor 2010: 52-53). ${ }^{11}$ He also mentions Charles Darwin's The expression of the emotions in man and animals (1872), and, in what was in all probability a reference to his studies of 1921, a "collection of essays by the Central Labour Institute in their application to work movement".12

Eisenstein's applications in the First Workers' Theatre of the Proletkult (where he worked in collaboration with Sergei Tretyakov) of the methods and techniques he had learned in the school of Meyerhold have been well described in Hielscher 1973, Hoover 1974, Gordon 1978 and Leach 1994. Here we shall focus upon what Eisenstein described as being his main purpose in applying scientific and aesthetic techniques on the stage and in film, namely to achieve the desired propaganda effect, or, as one scholar has put it, to "organize the cognition of the spectators" (Tikka 2009: 229). Indeed, we learn from an interview of 1928 that one of the modules of his Teaching and Research Workshop was devoted to "Ideological Expressiveness" - "the problem of the transition of film language from cinema figurativeness to the cinematic materialization of ideas, i.e., with the problems of the direct translation of an ideological thesis into a chain of visual stimulants" (Taylor 2010: 127-129). ${ }^{13}$ The film Strike, completed in 1924, Eisenstein's last year in the Proletkult, provides an insight into the kind of ideological messages that he was seeking to convey at this time.

\section{The ambivalent messages of Strike}

There is no 'programmatic' Marxism in Strike. The film had originally been conceived as the fifth of a series that would outline the history of the Russian workers' movement from the first underground printing press to the October Revolution, but the Communist Party had not yet come round to formulating an official version of the history of the revolution. Besides, as Mark D. Steinberg has pointed out, very few writers and artists working within proletarian cultural institutions during the 1920s considered themselves to be Marxists, and not only Marxist instructors taught within the Proletkult (Steinberg 2002: 52, 61). This doctrinal pluralism made possible a cross-fertilization of Marxist and non-Marxist ideas in the arts and this eclecticism is evident in Strike. ${ }^{14}$

A key message of Strike is that workers can prevail against adversity if they accept the need for 'organization' (the film opens with a lengthy quotation on this subject from Lenin, dated 1907). Surprisingly, however, in the end, such 'organization' as is achieved is not effective, and the strike ends in defeat. The concluding message is not the standard rallying call of Social Democratic and, later, Communist Parties: - "Workers of the world unite!", but a more sombre exhortation to "remember these things"; not the inevitable triumph of proletarian revolution, but a kind of radical ouvriérisme.

10 On the theoretical and practical work of the First Workers'Theatre see Leach 1994: 151-161.

11 For a fuller account of Eisenstein's adaptation of the ideas of these thinkers, see Bulgakowa 2001b: 175-178; and Bulgakowa 2014: 428-429.

12 The Central Labour Institute was headed by Aleksey Kapitonovich Gastev (1882-1939), a former'proletarian poet' and a disciple of Frederick Winslow Taylor, the pioneer of the "scientific organization of labour. In 1921, Bernstein had founded a biomechanics laboratory in the Central Institute of Labour. See Bulgakowa 2001a: 26. According to Edward Braun, the programme of Meyerhold's 'theatrical-technical school' drew upon the ideas of William James, Bekhterev, Pavlov, Taylor and Gastev (Braun 1995: 172-177).

13 The other two modules were devoted to "Human Expressiveness" and "Montage Expressiveness". For the range of connotations acquired by 'attraction' and 'montage' in the later theoretical writings of Eisenstein, see Bulgakowa $2001 \mathrm{c}$ : 41 and passim.

14 The relatively open membership policy of the Proletkult and the eclecticism of its activity in the arts are well described in Fitzpatrick 1970 and Mally 1990. 
In Strike, rank and file Bolshevik leaders are shown mobilizing worker activists in 'circles', but there is no didactic emphasis upon the leading role of the Party. Throughout the film the workers, whether in the factory, in a family setting, or as a crowd or 'collective' are represented as a force capable of moving of its own volition. ${ }^{15}$ This representation was consistent with Eisenstein's view of the importance of "mass material in establishing the ideological principle", as opposed to "the individual plot material of bourgeois cinema"16 and also with the founding philosophy of the Proletkult, which had originally conceived of itself as the 'third' wing of the labour movement, on a par with the party-political and trade union wings. ${ }^{17}$ It is significant that Eisenstein himself never became a party member.

\section{The intellectual and the proletarian}

The completion of Strike marked the point where Eisenstein's conception of revolutionary art could no longer co-exist with the traditionalist approach to theatre and film and the schematic Marxism of the Chairman of the Proletkult, Valeriyan Pletnëv. Differences in their social backgrounds may also have been a source of friction. Whereas Eisenstein was the son of a court councilor and engineer, Pletnëv (born in 1886, he was 12 years older than Eisenstein) had been born into a working class family and had earned his living for 19 years as a carpenter. A member of the Russian Social Democratic Party since 1904, Pletnëv had endured two periods of exile: in the Vologda Governorship, and in the Lena region of Siberia. He had begun writing in 1918 and by the early 1920s was considered to be a 'proletarian writer'.18 A preoccupation of his dramatic works was that of popular uprisings, and a Proletkult production The Avenger (Mstitel'), based on Revanche! Episode de la commune by Léon Cladel (Cladel 1878), had been enthusiastically reviewed by Bukharin in Pravda on 16 December 1919.19 The Paris Commune was also the theme of Flengo (Pletnëv 1922b), his stage adaptation of a story, Flingot (Paris, 1907) of Lucien Alexandre Descaves (1861-1949). ${ }^{20}$ Pletnëv's principal theatrical work was, however, Lena, a five-act play devoted to the massacre of gold mining workers in Siberia on 4 April 1912. In his introduction to the first edition of 1921, he had called upon "Poets, artists and actors" to take the struggles of the proletariat as their subject matter (Pletnëv 1921 b). In 1923, he published a lengthy history of events leading up to the massacre, and included his play as an appendix. ${ }^{21}$ Pletnëv's status as an authority, at least within the Proletkult, in matters relating to strikes, rested also upon his dramatization of a short story by Aleksey Gastev, entitled Strikes (Stachki), the text of which appeared under his own name in two editions in 1921 (Pletnëv 1921c, 1921d), and the following year under that of Gastev (Gastev 1922).

15 Eisenstein described the ideas expressed by him in Strike as "themes of the social mass". See "Beseda s rezh. S. M. Eyzenshteynom". Kino-nedalya 1925 (4): 17

16 See "The problem of the materialist approach to form" (1925) in Taylor 2010: 59-61; and Bulgakowa 2001a: 47-48.

17 On the aspirations of the Proletkult to an independent role in workers' education, inside Soviet Russia and internationally, see Biggart 2018.

18 His works included Na tikhom plëse (1919), a short story on the life of political exiles; his play Lena (1921); Andreykino Gore (1921) on the everyday life of the proletariat and the life of children before the revolution. In Bolotnye ogni (1921) he provides one of first postrevolutionary portraits of the kulak. See Literaturnaya Entsiklopediya 1934 and Kratkaya Literaturnaya Entsiklopediya 1968: 5.

19 Mstitel' was published in Ekaterinburg in 1920 and, to commemorate the 50 th anniversary of the Paris Commune, in Petersburg in 1921. In the edition of 1921 Pletnëv's name is omitted from the title page and there is an introductory dedication to the Paris Commune by A. Piotrovskiy. On Bukharin's review, see Fitzpatrick 1970: 147-149.

20 According to a "Repertoire of the Workers'Theatre of the Proletkult" published in Pletnëv 1921b, it would appear that Flengo had first been published in 1921

21 Pletnëv 1923. In 103 pages, Pletnëv outlines the history of the gold industry in Russia and of the company Lenskoe zolotopromyshlennoe tovarishchestvo ("Lenzoto"). He includes information on wages, working conditions, technology, the legal and material situation of the workers and photographs of the site of the massacre. The following year, a shorter version was published as a supplement to Kurskaya Pravda (Pletnëv 1924a) 
In December 1920, Pletnëv had succeeded Pavel Lebedev-Polyanskiy as Chairman of the Presidium of the Central Committee of the Proletkult, ${ }^{22}$ having acquiesced in the policy of the Communist Party that the Proletkult should concern itself with improving the productivity of labour. ${ }^{23}$ In November 1921 he was appointed Head of the Arts Section of the State Agency for Political Education, Glavpolitprosvet. (Fitzpatrick 1970: 238-242). By the time, therefore, that Eisenstein began working on Pletnëv's plays as a set-designer, Pletnëv was already a senior official of the cultural superstructure. It boded ill for Eisenstein that, whereas Lebedev-Polyanskiy had denounced as "demagogy" the idea that intellectuals could not create proletarian culture, ${ }^{24}$ Pletnëv was of the opinion that only a proletarian could give adequate expression to the proletarian mentality. ${ }^{25}$

\section{The "reactionary tendency"}

In March 1921, in the Second Central Studio of the Proletkult, ${ }^{26}$ Eisenstein and Leonid Nikitin had designed the sets and costumes for Valentin Smyshlyaev's production of The Mexican, a play based on a story by Jack London. ${ }^{27}$ The two subsequently designed sets and costumes for a production by Smyshlyaev and Vasiliy Ignatov of Pletnëv's Lena, which had its première in October 1921. ${ }^{28}$ However, the incompatibility of Eisenstein's vision with that of his Proletkult seniors soon became apparent: his stage effects for a production by Smyshlyaev of Pletnëv's On the Abyss (Nad obryvom) were rejected by Pletnëv (Yurenev 1985: 49). ${ }^{29}$ Eisenstein and Smyshlyaev "had a complete disagreement in principle that led to a split and subsequently to our working separately" (Taylor 2010: 33). ${ }^{30}$ Following the première in April 1923 in the First Workers'Theatre of The Wise Man (Eisenstein's debut as a director and the first implementation on stage of his 'theory of attractions'), ${ }^{31}$ Eisenstein and Pletnëv planned a production of the latter's detective play, Patatras, but preparations ground to a halt (Bulgakowa 2001a: 39). ${ }^{32}$

22 Lebedev-Polyanskiy had helped found the Proletarian University and had been Secretary of the International Bureau of the Proletkult. He claimed to have been a "dedicated defender of the idea of proletarian culture, proletarian science, proletarian art, proletarian literature." See his autobiography in Deyateli ... 1989: 489-491.

23 See the minutes of the Plenum of the Central Committee of 16-20 December 1920 and 15-20 May 1921 in Proletarskaya Kul'tura, 1921 (20/21). Pletnëv's initial attempt to find a middle way between Bogdanovism and Lenin's conception of socialism as "the Soviets plus electrification of the countryside" is well illustrated in his article, "Na ideologicheskom fronte", Pravda, 27 September 1922.

24 Proceedings of the Second Conference of the Moscow Proletkult (March 1919), RGALI, f.1230, I. 140. A year earlier, Lebedev-Polyanskiy had expressed the more nuanced view that socialist intellectuals could be "temporary helpers", but the cultural influence they brought to bear should be carefully scrutinized. In the final analysis, only the proletariat could "resolve" (razreshit) the question of proletarian culture". See his speech of 16 September 1918, in Protokoly Pervoy Vserossiyskoy Konferentsii Proletarskikh kul'turno-prosvetitel'nykh organizatsii 15-20 sentyabria 1918.g. Moscow: 1918. On the relationship between workers and intellectuals in the Proletkult, see Mally 1990: 115-121.

25 In 1922 he wrote that the class consciousness of the proletariat was "alien to the peasant, the bourgeois, the intellectual (intelligent) the doctor, lawyer, engineer - who were reared in the spirit of capitalist competition ..." See Pletnëv, "Na ideologicheskom fronte" in V.I. Lenin o literature i iskusstve 1967: 460.

26 On the network of Proletkult theatre studios, 1920-1923, see Leach 1994: 71.

27 According to both Yurenev and Leach, whilst Smyshlyaev was formally the director of The Mexican, Eisenstein was "the true begetter" and directed the play when it was revived in August 1923. The posters for the play in 1921 attributed it to "Smyshlyaev, Arvatov and Eisenstein". For photographs of the stage and costume designs of Eisenstein and Nikitin, see Yurenev 1985: 44-45, 47; and Leach 1994: 72,74-75. See also Bulgakowa 2001a: 21-23.

28 The production of Lena in 1921 was the work of both Ignatov and Smyshlyaev. Eisenstein assisted Leonid Nikitin with the set designs. See Nikitina 1996 which has an introduction and commentary by Andrei L. Nikitin, the son of Leonid Nikitin. For a photograph of one scene, see Leach 1994: 78-81.

29 Yurenev reproduces one of Eisenstein's graphics for this play. See also Leach 1994: 162 \& 199; and Bulgakowa 2001 a: 31

30 Smyshlyaev had been a pupil of Konstantin Stanislavskiy in the Moscow Arts Theatre. See Yurenev 1985: 42; and Bulgakowa 2001a: 31

31 On this adaptation by Sergey Tret'yakov of Aleksandr Ostrovskiy's Enough stupidity for every wise man (Na vsyakogo mudretsa dovol'no prostoty), see Yurenev 1985: 62-67; Leach 1994: 142-150, with a photograph of one scene on page 148; and Bulgakowa 2001a: 36-38.

32 According to a report in Gorn 1923 (9), Eisenstein and Pletnëv were at his time collaborating in the production of a three-act detective play and over a play entitled Naslednik Garlanda, but it is not known whether the latter was ever performed or even written. See Yurenev 1985: 68. 
By this time, Eisenstein and the neo-Futurist playwright and critic, Sergey Tretyakov, saw themselves as the principal source of theatrical innovation in the Proletkult. After The Wise Man, Eisenstein in November 1923 directed Tret'yakov's Are You Listening Moscow? (Slyshish', Moskva?) and then, in February 1924, Tret'yakov's Gas Masks (Protovogazy). But "the group came under unrelenting attack from Bolshevik critics and less adventurous artists alike" (Leach 1994: 151). In "Montage of attractions" (1923), Eisenstein attributed this hostile response to differing understandings of what constituted revolutionary theatre: there had been a reactionary tendency within the Proletkult - "The figurative-narrative theatre (static, domestic - the right wing: The Dawns of Proletkult, ${ }^{33}$ Lena, and a series of unfinished productions of a similar type. It was the line taken by the former Workers'Theatre of the Proletkult Central Committee." (Taylor 2010: 33). In 1926, he provided further detail: "In 1922 I became the sole director of the First Workers'Theatre and I got involved in the most violent differences of opinion with the leaders of the Proletkult. The Proletkult people shared Lunacharskiy's view: they favoured making use of the old traditions and were not afraid of compromise when it came to the question of the relevance of the pre-revolutionary arts..$^{34}$ I was one of the most uncompromising champions of LEF, the left front, which wanted a new art that corresponded to the new social relationships. All the younger generation and all the innovators were on our side at that time, including Meyerhold and Mayakovskiy; ranged against us were Stanislavskiy, the traditionalist, and Tairov, ${ }^{35}$ the opportunist" (Taylor 2010: 74). In 1924, in his unpublished 'Montage of film attractions', without naming either Lunacharskiy or Pletnëv, Eisenstein made no effort to conceal his contempt for their conception of theatre and in particular for Pletnëv's commitment to a linear-thematic script. It was the merit of 'montage' that it "liberated film from the plot-based script" (Taylor 2010: 40-41). A script, "whether plot-based or not", should be "a prescription (or list) of montage sequences". The approach of "our scriptwriters" to the construction of a script was "utterly feeble", and this task should fall entirely to the director (Taylor 2010: 46).

\section{The anti-Proletkult campaign}

Not only artistic, but also party-political factors were involved in Eisenstein's departure from the Proletkult. By 1924, both Pletnëv and the Proletkult were coming under increasing pressure from the Agitprop Department of the Central Committee of the RK (b) and this may help to explain why Pletnëv felt he could no longer take the risk of harbouring within the Proletkult such a maverick as Eisenstein.

In September 1922, Pletnëv had felt able, in an article in Pravda entitled "On the ideological front", publicly to defend the mission of the Proletkult to develop proletarian culture. ${ }^{66}$ However, one month later he had been subjected to a humiliating rebuff by Yakov Yakovlev, the Deputy Head of the Agitprop Department, in an article that had been prepared in consultation with Lenin and which coincided with the anniversary of the October Revolution. ${ }^{37}$ In one section of this article, 'On Proletkult theatre', Yakovlev had articulated what was, in fact, Lenin's position, namely that during a period of transition it was more important to assimilate the achievements of bourgeois culture than to attempt

33 The Dawns of the Proletkult, an anthology by Vasiliy Ignatov of the verse of several proletarian poets and adapted for the stage by Smyshlyaev, was performed in the Central Arena of the Proletkult in 1920. One of Eisenstein's first tasks in the Proletkult was to assist Leonid Nikitin with the visual effects. See Yurenev 1985: 42, 44; and Leach 1994: 76-77.

34 Anatoliy Lunacharskiy was at this time the Commissar for Education. On his conservative policies regarding the theatre and Platon Kerzhentsev's 'leftist' critique of his plays, see Fitzpatrick 1970: 139-161.

35 Aleksandr Tairov was the founder and producer-director of the Kamernyy Theater, "famous for its highly stylized productions of exotic decadent plays and multi-level decorative scenery" (Bulgakowa 2001a: 283)

36 See Pletnëv, "Na ideologicheskom fronte", Pravda, 27 September 1922.

37 Yakovlev, "O 'proletarskoi kul'ture'i Proletkul'te", Pravda, 24 \& 25 October 1922, The discussions between Lenin and Yakovlev are described in V.I. Lenin o literature i iskusstve 1967 and in Gorbunov 1974: 192-193. 
"artificially" to create a proletarian culture. ${ }^{38}$ Yakovlev had apparently attended performances of The Mexican and of Lena. The representation of the revolution in The Mexican, he complained, in no way corresponded to the Russian worker's experience of class struggle. The production was "dynamic and entertaining" enough, but an American audience would struggle to find anything "proletarian" in it.39 Lena had some revolutionary content, he went on, but the first act was spoiled by quasi-Futuristic effects, and there was "a transition to somewhat hackneyed crowd scenes in the style of the Bolshoy Theatre". Representation of the proletarian masses was deficient - "five actors emitting a friendly ' $u-u-u$ ' in unison will never transform a crowd into the hero of the action."40 Yakovlev was unhappy that the Proletkult repertoire included a number of "individualistic" and "counter-revolutionary" foreign plays that had come to Russia after the Revolution of 1905, notably Flengo $0^{41}$ and The Avenger. Audiences who needed representations of the proletariat, were instead being served up with the fine flowers of decadent art and an imitation of Futurism. No matter how many carpenters and stagehands (montëry) laboured on these agit-plays (agitki) they would never be transformed into "artistic productions".42

Yakovlev's denounced not only the Proletkult's conception of theatre but also its assumption that its methods were specific to a proletarian phase of cultural development: the Proletkult, in its theses "On the tasks of the proletariat in physical culture", had proclaimed that "the new physical culture of the proletariat consists of the psycho-physiological education of the qualified individual."This ignored the fact that it the bourgeoisie was also organizing sport for the masses, and organizations like Sokol were inculcating nationalist ideas into the younger generation, using the very same methods that the Proletkult considered to be essentially "proletarian".43 Yakovlev went on to cite Eisenstein's mentor, Meyerhold, against him: on 12 June 1922, Meyerhold (a "representative of the left-Futurist persuasion"), had delivered a lecture in the Concert Hall (Malyy Zal) of the Conservatoire on the subject of "The actor of the future". Meyerhold had argued that "Physical training (fizkul'tura) acrobatics, dance, rhythmics, boxing, fencing ... were useful subjects, and would bring benefit if they were taught in conjunction with 'biomechanics' - an essential subject for every actor." Meyerhold, had done much to bring the theatre into line with the "crazy tempo" of modern life; and he had not been so foolish as to employ the term "proletarian culture".

Yakovlev's diatribe was not aimed solely at Pletnëv; indirectly he sought to disparage Aleksandr Bogdanov and Nikolay Bukharin, one of the Communist Party's leading Marxists, who had in some respects been influenced by Bogdanov. ${ }^{44}$ Notwithstanding the fact that in December 1920 Bogdanov had stepped down from his leading role in the Proletkult, and by November 1921 had completely withdrawn from the institution, Lenin had come to the conclusion that, as in the past, Bogdanov was a political, as well as an intellectual threat. ${ }^{45}$ On 4 January 1923, in an article, entitled "Menshevism in

38 For Lenin's sarcastic annotation of the article by Pletnëv, see V.I. Lenin o literature i iskusstve 1967, 457-466.

39 Yakovlev, "O'proletarskoi kul'ture'i Proletkul'te", Pravda, 24 \& 25 October 1922, in Voprosy kul'tury pri diktature proletariata 1925 : 39.

40 Yakovlev, "O 'proletarskoi kul'ture' i Proletkul'te", Pravda, 24 \& 25 October 1922, in Voprosy kul'tury pri diktature proletariata 1925: 39-40. Pletnëv had earlier hailed the 1921 production of his own play as being, "for all its weakness... the first shaft of light of a proletarian theatre". See 'Na ideologicheskom fronte', Pravda, 27 September 1922, in V.I. Lenin o literature i iskusstve 1967: 465.

41 Judging by Yakovlev's article, Flengo must have been performed before 24-25 October of 1922. For a résumé of the plot and a photograph of the production of Flengo by Vladimir Tatarinov, see Leach 1994: 78-79. On 1 February 1925 Flengo was performed in the Bolshoy Theatre as a "musical dramatization of an episode of the time of the Paris Commune", with music by Vladimir Tsybin and a libretto by "V.Pletnëv and Tyshko". See http://www.bilet-bolshoy.ru/old-repertoire/flengo

42 Yakovlev, "O'proletarskoi kul'ture' i Proletkul'te", Pravda, 24 \& 25 October 1922, in Voprosy kul'tury pri diktature proletariata 1925 : 40.

43 Yakovlev, "O'proletarskoi kul'ture' i Proletkul'te", Pravda, 24 \& 25 October 1922, in Voprosy kul'tury pri diktature proletariata 1925, 42-43. Yakovlev quotes Meyerhold from the journal Ermitazh (6): 41.

44 Bukharin, whose ideas on culture owed something to Bogdanov, asserted at a conference convened by the Central Committee in February 1925, that Lenin, through the article of Yakovlev, had been criticizing not only the Proletkult but also himself. See Bukharin 1925 (4): 265; and Biggart 1992: 131-158.

45 Bogdanov was not re-elected to the Presidium of the Central Committee of the Proletkult in December 1920, but remained a member of the Central Committee. See the minutes of the Central Committee of the Proletkult and of its Presidium for the period December 1920 to May 1920 in RGALI, f.1230 and in Proletarskaia kul'tura 1921 (20/21): 32-37. In an autobiographical sketch of 1925 Bogdanov wrote that "In the autumn of 1921 my work in the Proletkult came to an end and I devoted myself exclusively to scientific work.". See Bogdanov, A.A. (Malinovskiy) 1995: 19 and 60, fn.20. 
Proletkult attire", Yakovlev returned to the attack and denounced Bogdanov's views as being inherently oppositional and conducive to the formation of a new political "group or party". The Proletkult, he averred, was merely a first step in this direction. ${ }^{46}$ Then, some time before August 1923, an anthology was published under the title Against A. Bogdanov, ${ }^{47}$ which contained works not only by Lenin but also by G.V. Plekhanov, whose understanding of Marx had since the turn of the century been the butt of Bogdanov's criticism. Finally, the suspicion that Bogdanov had encouraged the formation of the oppositional Workers' Truth group led to his detention, between 8 September and 13 October 1923, by the GPU.48

Given that the public campaign against Bogdanov coincided with Eisenstein's period of activity within the Proletkult, and given the closeness of Eisenstein's working relationship with Pletnëv, Eisenstein could hardly have been ignorant of the fact that Bogdanov was now an outcast. ${ }^{49}$ This seems to be the most likely explanation for the absence of any mention of Bogdanov in Eisenstein's works of this period and of later years. ${ }^{50}$ Pletnëv, for his part, had by May 1924 fallen completely into line with the policy of Agitprop and was calling for "not several, but a single revolutionary Marxist criticism".51 In the same year he went out of his way publicly to dissociate himself from "Bogdanovism".52

\section{Eisenstein's exit from the Proletkult}

Relations between Eisenstein and Pletnëv approached their nadir when, in mid-November 1924, Eisenstein refused to participate in a component of the planned programme of the Workers' Theatre that included two plays by Pletnëv. His departure from the Proletkult soon followed. In January 1925 he gave his reasons in separate interviews published in Novyy zritel' and Kino-nedelya, shortly after Strike had been completed and while the film was awaiting approval by the censor. He had turned his back on Pletnëv's plays "because of their formal and theatrical qualities" (Eisenstein 1925b: 22).

In Eisenstein's vocabulary "theatrical" was, of course, a term of contempt, but his criticism of the Proletkult ranged more widely: in Novyy zritel' in 1925 he deplored the absence of any orientation (formal or in terms of content) in the repertoire of the Proletkult theatre. The repertoire had been constructed in haphazard fashion and since The Wise Man, only the two plays of Tret'yakov had followed a consistent political line. In the forthcoming repertoire there was not a single play that had articulated a clear message. Priority was being given to performances for the urban districts, for which the Proletkult theatre was not suited: during his four years with the Workers'Theatre its policy had been to concentrate on practical exercises for the actors, putting on shows (spektakli) and on working out formats for agit-bouffe and agit-guignol, so that this experience could in due course be passed on to the districts and the provinces. He complained of "harassment" (gonenie) that had begun as early as his staging of The Wise Man, which had been removed from the repertoire after the general rehearsal in 1922 and then re-instated. In the current season, interference had assumed unacceptable forms: the Artistic Council of the Theatre, without informing him, had removed a number of "tricks" from The

46 Yakovlev, "Men'shevizm v Proletkul'tovskoy odezhde”, Pravda 4 January 1923

47 V. I. Lenin \& G. V. Plekhanov 1923.

48 This episode is dealt with in Biggart 1990 (3): 265-282.

49 Not all leading party officials ostracized Bogdanov. He continued to be highly regarded by Bukharin, Krasin and others. In December 1925, the Commissar for Health, Nikolay Semashko, supported the founding of Bogdanov's Institute for Blood Transfusion. Stalin was well disposed towards Bogdanov during his lifetime.

50 Lenin's anathematization of Bogdanov was taken up by Stalin after Bogdanov's death in 1928, which is doubtless one explanation why, even in his memoirs of 1946, Eisenstein makes no mention of Bogdanov.

51 "ne raznaya, a odinakovaya revoyiutsionnaya Marksistskaya kritika". See the contribution of Pletnëv to a conference convened by the Press Department of the Central Committee of the RKP(b) on 9 May 1924 and chaired by Yakovlev, in Kvoprosu o politike RKP(b) v khudozhestvennoy literature 1924: 48. In the introduction to this volume, Yakovlev notes that it had originally been intended to hold the conference "a year earlier".

52 Pletnëv now claimed that whereas he, Pletnëv, was engaged in "practical work", Bogdanov was an abstract theorist. Bogdanov's theory that proletarian culture was "socialist culture in the process of development" was identical to that of Trotskiy (Pletnëv 1924b: 37). 
Wise Man and introduced verbal components of their own. A number of elements had been removed from the last "fight" scene in Are you listening Moscow? Grigoriy Roshal, whose approach to theatre was diametrically opposed to his own, had been brought in. Arbitrary appointments of this nature made it impossible to create a theatre with its own identity. In general, the Proletkult had adopted the role of a 'censor': ninety percent of its concerns were with ideological conformity and the fidelity of a production to the details of everyday life. Its approach to both theatre and film was one of "petty-bourgeois realism" (Eisenstein 1925c: 13-14).

In Kino-nedelya in 1925 Eisenstein described the circumstances of his departure from the Proletkult during the first week of December 1924. The occasion had been the "failure of the Proletkult Executive Bureau to recognize my rights as co-author of the script of Strike". But this had arisen out of a more deep-seated struggle between his own, revolutionary, conception of the theatre and that of the Proletkult leadership: "Over the past year my work could not conform with the manifestly reactionary direction (theatrically, formally) taken by the ruling circles of the Proletkult, commencing with the acquisition of influence by people who had always opposed my approach and who stubbornly defended the 'rightist' point of view in the theatre ... The subsequent direction of work in the Proletkult marked a complete break with the 'left front' and, therefore, a strengthening of the position of our enemies in the theatre" (Eisenstein 1925a: 17). Two issues later, in the same journal, Pletnëv dismissed Eisenstein's claim to represent the cultural avant-garde: Eisenstein possessed only a "formally revolutionary orientation" - one that amounted to mere "leftism". This tendency "manifested itself in a striving for superfluous, self-directed formalism and gimmickry in working out the director's plan for the film; and in the introduction into the plan of a number of incidents of dubious Freudian purport" (Pletnëv 1925: 9).

\section{Eisenstein, Marxism and 'Bogdanovism'}

\section{Varieties of organization theory}

In 1933, Eisenstein wrote that his "personal research and creative work" had from the outset been accompanied by a "study of the founders of Marxism" (Taylor 2010: 244), but in his writings of the 1920s there are only passing and, it sometimes seems, dutiful references to 'materialism', 'collectivism', 'organization' and the 'dialectic'. Neither in his memoirs, nor in any of his theoretical works, does he give any indication that he was influenced by Bogdanov. ${ }^{53}$ Can we nevertheless discern conceptual affinities between the two? Charlotte Douglas has noted that the revolutions of 1917 made possible a wide dissemination of Bogdanov's ideas within the literary and artistic community: the head of the Petrograd Visual Arts Section of the Commissariat for Education, Nikolay Punin, in lectures read to teachers in 1919 "followed Bogdanov's ideas and terminology closely." Artists such as Lyubov Popova (an associate of Eisenstein) and Solomon Nikritin, employed the language of 'organization'. According to Douglas "the organizational order and high level of abstraction in Bogdanov's Tektologiya lent scientific authority to the artistic structures of constructivism and projectionism", and there was a "common conceptual basis", even if this "did not result in an identifiable style of abstraction" (Douglas 2002: 81-82, 92).

Mikhail Yampolskiy, citing V. Zabrodin, has referred to a debate in the Proletkult during which Eisenstein called for a struggle for "1) the organized society... 2) the organized human being", and has detected "behind these formulae ... the Proletkultist-Bogdanovist 'Tektology', the science of organization" (Yampolskiy 2005). ${ }^{54}$ However, whilst Tektology might well have influenced Eisenstein's thinking, ideas on organization during his Proletkult years could just as well have come from other sources.

53 Sergey Mikhailovich Eisenstein (1898-1948) wrote his memoirs in 1946. The complete text was published in Russia only in 1997.

54 Yampolskiy is mistaken in identifying the Proletkult exclusively with Bogdanov and both with iconoclasm. See Yampolskiy 2005: 49. 
The theatre critic, Platon Kerzhentsev, who spoke at the First Conference of the Proletkult in September 1918 and became a member of the editorial board of Proletarskaya kul'tura, had written a book on organization and was one of the founders of the journal The Time League (Liga Vremeni - Liga NOT). Kerzhentsev was a fierce critic of Bogdanov's organization theory. ${ }^{55}$ Such prominent leaders as Lenin, Trotskiy and Krasin were all, at this time, advocates of the "scientific organization of labour".56 Krasin had always been close to Bogdanov, but Lenin and Trotskiy were amongst his fiercest critics.

\section{Art as cognition and art as propaganda}

Did Bogdanov's theory of the social function of art influence Eisenstein's 'theory of attractions'? For Eisenstein, "the theatre's basic material derives from the audience: the moulding of the audience in a desired direction (or mood) ..." (Taylor 2010: 33-36). For Bogdanov, the function of art was both cognitive and educational: "firstly, to organize a particular sum of the elements of life, of 'experience'; and, secondly, to ensure that what is created serves as an instrument for a particular collective.".57 The difference is that, for Bogdanov, cognition was one of the interactive processes of social selection, whereas Eisenstein at this time viewed art as an instrument of agitation and propaganda, consciously applied, one might almost say'from above.58

\section{Organizational aesthetics}

In the case of one writer who was close to Eisenstein, there is a more evident affinity with the ideas of Bogdanov. The critic Boris Arvatov, who for some time worked as an 'academic secretary' in the Proletkult and who had collaborated in the production of The Mexican and in designing the programme of the directing workshop of the Proletkult, contributed articles on the culture of everyday life to both LEF and Proletkult journals. ${ }^{59}$ The use of objects to convey social meaning in certain episodes of Strike might well reflect the influence of Arvatov. ${ }^{60}$ Furthermore, for Arvatov, the artist in socialist society was essentially a designer whose works would acquire meaning only when "subordinated to the production process ... to the collective's socially conscious and free will: integrality and organizedness are the premises of industrial art; purposefulness is its law" (Arvatov 1922 in Bowlt 1991: 229-230; Chehonadskih 2018: 5). Art was to be regarded as "simply the most efficacious organization in any field of human activity" (Arvatov 1926: 88-89). Here we are close to Bogdanov's contention that "all of the usual human evaluations that take the form of such concepts as goodness, beauty and truth, that is, moral, aesthetic and cognitive evaluations ... are organizational evaluations (Bogdanov 1922: 516).

Arguably, Eisenstein was enunciating a similar theory in 1924, when he wrote that, just as the movements of animals, structured in strict accordance with organic laws and unaffected by the "rational principle" were photogenic, and just as the labour processes of workers which flowed in accordance with these laws had been shown to be photogenic, so a successful realization by the actor and director of a montage (assembly) of movements that were purely organic in themselves would be the most photogenic, "in so far as one can define 'photogenic' by paraphrasing Schopenhauer's good old definition of the 'beautiful!' In this example Eisenstein's "level of organization" is the degree of approximation of the actor and director to organic movement. He goes on to express his

55 Kerzhentsev's Printsipy organizatsii (1918), ran to four editions. His Tvorcheskiy teatr (1918), reached its fifth edition in 1923. In Pravda for 14 April 1923 he criticized Bogdanov's Tektologiya as "reactionary". See "O kritikakh 'Tektologii" (1925), in Bogdanov 1996: 308-315. For Kerzhentsev's autobiography, see Deyateli ... 1989.

56 See E.B. Koritskiy, "Pervye stranitsy NOT", in U istokov NOT 1990. Two surveys by Sergey Chakhotin on Western experience of organization science had been published in Russia in 1924. His bibliography on the subject was published under the auspices of the People's Commissariat of the Workers'-Peasants' Inspectorate (Rabkrin), which had been given responsibility for the "rationalization" of state institutions (Chakhotin 1924a; Chakhotin 1924b).

57 "O khudozhestvennom nasledstve"'(1918), in Bogdanov 1924/1925: 150.

58 See, for example, “The method of making a workers' film” (1925), in Taylor 2010: 65-66.

59 On Arvatov, see Lodder 1983: 239; Zalambani 1999; Bulgakowa 2001a; and Chehonadskih 2018).

60 See Arvatov 1925; Kiaer 1997: 105-118; and Albera 1990: 179-184. From materials in the Bogdanov Family Archive we know that Arvatov borrowed books on scientific subjects from Bogdanov. 
appreciation of the uniforms of the Japanese General Staff, and of working clothes (e.g., a diving suit), as "functional forms" that can be considered "photogenic" (Taylor 2010: 56-57). Here, as with Arvatov, we have a functionalist aesthetic that is cognate with, if not identical to, Bogdanov's "whatever raises the level of organization of collective life ... in perceptions of the world (mirovospriyatiya) is deemed to be beautiful" (Bogdanov 1922, 516).

\section{After the Proletkult}

In an interview of 1926, Eisenstein denied that there had been any conflict in his relations with his working class associates in the Proletkult: "At that time, these workers were in complete agreement with my artistic views and requirements, although I really belonged to another class and had come to the same point of view only through purely theoretical analysis." His exasperation had been with the artistic conservatism of the Proletkult leadership (Taylor 2010: 74). In a diary entry for 24 February 1927 Eisenstein made it clear that by November 1924 he had had enough of what he disparagingly refers to as "theatre": 'I did not want to do theatre in the Proletkult; I wanted to design new templates to solve experimental problems - Agit-revues (The Wise Man) or political agit-plays (Are you listening, Moscow?) to be staged throughout the entire network of provincial Proletkults. The Proletkult wanted to use our laboratory retorts to cook jam - to make theatre (out of the plays of Pletnëv!) and professional theatre at that! This was one of the biggest differences between us" (Yurenev 1985: 99).

Eisenstein's career was not damaged by his departure from the Proletkult; if anything, the contrary. In January 1925 he declared that he was not willing to collaborate with the Proletkult in the next seven parts of a film series on the 'Dictatorship', for which the Proletkult had the contract (Eisenstein 1925c). But that same month the Commissar for Education (and cultural 'conservative'), Anatoliy Lunacharskiy, invited him to make a film celebrating the twentieth anniversary of the revolution of 1905 under the direct auspices of Goskino, an invitation which he accepted (Yurenev 1985: 106-109; Bulgakowa 2001a: 56). Although both Eisenstein and Pletnëv were appointed to the committee that was to oversee the project, it is evident that they could not have worked together in the making of the film. ${ }^{61}$ Eisenstein had by this time found a new patron in Kirill Ivanovich Shutko, who had acted as his adviser at the request of Goskino during the making of Strike, and who had acquired responsibility for cinema in the same Agitprop Department of the Central Committee that had excoriated Pletnëv. Eisenstein and N.F. Agadzhanova-Shutko were appointed as authors of the script. ${ }^{62}$ His reputation enhanced by the success of Strike, Eisenstein was now able to embark upon a new stage in his career and upon new explorations in theory.

\section{Commentary by lan Christie}

That the relationship between Sergei Eisenstein and the Proletkult, under Pletnëv's leadership, would become confrontational was, in retrospect, entirely predictable. As Biggart and Bulgakowa make clear, in providing more background on Pletnëv's emergence as a dramatist than is customary, his life experience and his thematic preoccupation with strikes and worker self-organisation were entirely consonant with the ideals of Proletkult - more so, indeed, than the experience of its founder, the

61 Other members of the committee were Malevich, Meyerhold, Pletnëv, Shutko, Krasin and the First Secretary of the Moscow City Committee of the RKP (b), Vasiliy Mikhaylov. See Yurenev 1985: 106-109.

62 On this episode see Bulgkowa 2001a: 53, 56. 
physician and polymath Aleksandr Bogdanov. Just as predictable, with historical hindsight, was Lenin's move in 1920 to stem the influence of Proletkult, leading to a period when it was tolerated as a purely cultural organisation, subsumed within Narkompros.

Biggert and Bulgakowa provide an admirably detailed account of the doctrinal and political issues at stake during this transitional period, which can be characterized as allowing 'doctrinal pluralism' and eclecticism. But beneath such analysis, we can see a number of other factors at work, which might be termed social and personal elements. They point to the clear class hostility between Pletnëv and Eisenstein, a worker who had become a cultural-political leader, and a precocious young intellectual, making his way in theatre. Despite the fact that both had been influenced by Bogdanov's ideas, it had become politic not to allude to these openly, even if we can see clear traces of such ideas in the 'workerism' of both Strike and Potemkin. And although we can only assess the impact of Eisenstein's theatre productions under the Proletkult banner from his designs and the film fragment Glumov's Diary, it is valuable to have Yakov Yakovlev's highly critical denunciation of such avant-garde provocation.

Eisenstein's solution to the complex and treacherous political situation of the mid-1920s following Lenin's death was to stress the 'scientific' direction of his work - hence, the revealing diary entry quoted from 1927: 'I did not want to do theatre in the Proletkult; I wanted to design new templates to solve experimental problems'. Drawing on an eclectic combination of behavioural and biological sciences to justify his 'experiments' would become a theoretical justification for what were, in truth, distinctly avant-garde impulses. From our expanding knowledge of Eisenstein's interests and infatuations, we must surely recognize that he was much more intuitive, and indeed eclectic, than he was willing to admit. It shouldn't be disloyal to admit that he was extremely adept at rationalising his impulses, and indeed covering his tracks within the dangerous world of Soviet cultural politics. What I draw from Biggert and Bulgakowa's surefooted analysis of the 'Proletkult period' is a better understanding of how Eisenstein used the 'pluralism' of the early 1920s to gain experience, to push against boundaries, and indeed to advance his reputation. Despite the very real tensions, both sides benefited from the work of this period and its lasting impact.

\section{References}

Albera, F. 1990. Eisenstein et le constructivisme russe. Lausanne: L'Age d'Homme.

Arvatov, B. 1922." "The proletariat and leftist art", translation of "Proletariat i levoe iskusstvo". Vestnik iskusstv 1922 (1), in Bowlt, John E. (Ed.) 1991: 229-230.

Arvatov, B. 1925. "Byt i kul'tura veshchei". Edited and translated from Al'manakh Proletkul'ta, by Christina Kiaer. October (81): 119-128.

Arvatov, B. 1926. Iskusstvo i proizvodstvo. Moscow: Proletkul't.

Biggart, J. 1990. "Alexander Bogdanov and the theory of a new class". Russian Review (3): 265-282.

Biggart, J.1992."Bukharin's Theory of Cultural Revolution", in Anthony Kemp-Welch (Ed.), The Ideas of Nikolai Bukharin. Oxford: Clarendon Press, 131-158.

Biggart, J. 2018. "Alexander Bogdanov and the short history of the Kultintern". https://www.academia.edu/37754739

Bogdanov, A. 1922. Tektologiya. Vseobshchaya organizatsionnaya nauka. Petersburg, Moscow, Berlin: Grzhebin.

Bogdanov, A. 1924/1925. O proletarskoy kul'ture 1904-1924. Leningrad-Moscow: Kniga.

Bogdanov, A. 1925. "O kritikakh 'Tektologii", Appendix to the third edition of Vseobshchaya organizationonnaya Nauka - Tektologiya. I. Moscow \& Leningrad: Kniga. 
Bogdanov, A. 1995. Stat'i, doklady, pis'ma i vospominaniya 1901-1928. In Neizvestnyy Bogdanov, Kniga 1, edited by N.S.Antonova \& N.V.Drozdova. Moscow: ITs "AIRO - XX".

Bogdanov, A. 1996. Bogdanov's Tektology, Book 1. Edited and translated by Peter Dudley, Vadim N. Sadovsky and Vladimir V. Kelle, Hull: University of Hull (Centre for Systems Studies).

Bowlt, JE. (Ed.) 1991. Russian Art of the Avant Garde. Theory and Criticism. London: Thames and Hudson.

Braun, E. 1995. Meyerhold: A Revolution in Theatre. London: Methuen.

Bukharin, NI. 1925. "Proletariat i voprosy khudozhestvennoy politiki", Krasnaya nov', Nr.4.

Bulgakowa, O. 2001a. Sergei Eisenstein. A Biography. Berlin, San Francisco: Potemkin Press.

Bulgakowa, O. 2001 b. “La conférence berlinoise d"Eisenstein: entre la psychanalyse et la gestaltpsychologie", in: Chateau, Dominique, François Jost, Martin Lefebvre (Eds.), Eisenstein: l'ancien et le nouveau, Paris: Publications de la Sorbonne, 171-183.

Bulgakowa, O. 2001c. "The Evolving Eisenstein. Three Theoretical Constructs of Sergei Eisenstein". In Eisenstein at 100. A reconsideration, edited by Al Lavalley and Barry P. Scherr. New Brunswick, New Jersey and London: Rutgers University Press, 389-451.

Bulgakowa, O. 2014. "From expressive movement to the 'basic problem': the Vygotsky-LuriaEisensteinian theory of art". In The Cambridge Handbook of Cultural-Historical Psychology, edited by Anton lasnitskii and René van der Veer. Cambridge: Cambridge University Press, 423-448.

Bulgakowa, O. 2022. 'Circus and the Soviet Avant-Garde', in Anna-Sophie Jürgens \& Mirjam Hildbrand (Eds.), Circus and the Avant-Gardes: London: Routledge.

Chakhotin, SS. 1924a. Evropeiskaya literatura po NOT. Moscow: NRKKI.

Chakhotin, SS. 1924b. Organizatsiya. Printsipy, metody v proizvodstve, torgovle, administratsii i politike. Moscow-Petrograd: Gos.izdat.

Chehonadskih, M. 2018. 'The Stofflikhkeit of the Universe: Alexander Bogdanov and the Soviet Avant-Garde', e-flux journal \# 28-february. 1-9.

Cladel, L. 1878. Revanche! Episode de la commune, in Mon ami le sergent de ville; Nazi; Revanche! (Episode de la commune). Brussels: H. Kistemaeckers.

Clark, K. 1995. Petersburg. Crucible of Cultural Revolution. Cambridge, Mass. \& London: Harvard University Press.

Descaves, LA. 1907. Flingot. Paris: A. Romagnol. Deyateli SSSR i revoliutsionnogo dvizheniya Rossii 1989. Moscow: Sovetskaya Entsiklopediya.

Douglas, C. 2002."Energetic abstractionism: Ostwald, Bogdanov, and Russian post-revolutionary art". From Energy to Information. Representation in Science and Technology, Art, and Literature, edited by Bruce Clarke and Linda Dalrymple Henderson, Stanford, California: Stanford University Press.

Eisenstein, SM. 1925a. "Beseda s rezh. S.M.Eyzenshteynom". Kino-nedelya (4): 17.

Eisenstein, SM. 1925b. "Pis'mo v redaktsiiu". Kino-nedelya (10): 22.

Eisenstein, SM. 1925c. "S. Eyzenshteyn i Proletkul't (Beseda s SM. Eyzenshteynom)". Novyy zritel' (4), 27 January: 13-14.

Eisenstein, SM. 1997. Memuary, I. Moscow: Redaktsiya gazety "Trud". Muzey Kino.

Fitzpatrick, S. 1970. The Commissariat of Enlightenment. Soviet Organization of Education and the Arts under Lunacharsky. Cambridge: Cambridge University Press.

Gastev, A. 1922. Stachka. Instsenirovka V.F. Pletnëva. Moscow: Izdanie Mosk.Kom. RKSM.

Gorbunov, VV. 1974. V.I.Lenin i Proletkul't. Moscow: Izdatel'stvo Politicheskoy Literatury.

Gordon, M. 1978. "Eisenstein's Later Work at the Proletkult". The Drama Review. Volume 22, Issue 3, 107-112.

Hielscher, K. 1973. "S.M. Eisensteins Theaterarbeit beim Moskauer Proletkult, 1921-1924", Ästhetik und kommunikation, No.13, 64-75.

Hoover, ML. 1974, "Meyerhold's legacy: Eisenstein and the Theatre Today in Russia and the West", in 
Meyerhold. The Art of Conscious Theatre. Amherst: The University of Massachusetts Press.

K voprosu o politike RKP (b) v khudozhestvennoy literature, 1924. Moscow: Izdatel'stvo "Krasnaya nov"'. Glavpolitprosvet.

Kerzhentsev, PM. 1922. Printsipy organizatsii. Petrograd: Gos.izdat.

Kerzhentsev, PM. 1923. Tvorcheskiy teatr. $5^{\text {th }}$ edition, Moscow - Petrograd: Gos.izdat.

Kiaer, C. 1997. "Arvatov's Socialist Objects", October (81), 105-118.

Kratkaya Literaturnaya Entsiklopediya 1968. 5, Moscow: Sovetskaya Entsiklopediya

Leach, R. 1994. Revolutionary Theatre. London and New York: Taylor \& Francis

Lenin, VI. and Plekhanov, GV. 1923. Protiv A. Bogdanova. Moscow: Krasnaya nov'.

Leyda, J. (Ed.) 1968. Film Essays with a Lecture. Sergei Eisenstein. London: Dobson.

Literaturnaya Entsiklopediya 1934. VII, Moscow: Kommunisticheskaya Akademiya.

Lodder, C. 1983. Russian Constructivism. New Haven and London: Yale University Press.

Mally, L. 1990. Culture of the Future. The Proletkult Movement in Revolutionary Russia. Berkeley, Los Angeles, Oxford: University of California Press.

Nikitina, VR. 1996. Dom oknami na zakat: Vospominaniya. Moscow: Intergraf Servis

Olenina, AH. 2020. Psychomotor Aesthetics: Movement and Affect in Modern Literature and Film: New York: Oxford University Press.

Pletnëv, VF. 1920. Mstitel'. Instsenirovka po rasskazu Kladelya v odnom deystvii. Ekaterinburg: Gos.izdat.

Pletnëv, VF. 1921a. Mstitel' Leona Kladelya (Pamyati Parizhsoyi Kommuny 1871-1921). Peterburg: Petropolitprosvet.

Pletnëv, VF. 1921 b. Lena. Proletarskaya drama v 5-ti deystviyakh. Rostov on Don: Gos.izdat., Donskoe otdelenie.

Pletnëv, VF. 1921c. Stachki. Instsenirovka po rasskazu Gasteva. Moscow: Moskovskii Proletkul't.

Pletnëv, VF. 1921 d. Stachki. P'esa v 1 deystvii. Ekaterinburg: Gos.izdat.

Pletnëv, VF. 1922a. "Na ideologicheskom fronte". Pravda, 27 September, in V.I. Lenin o literature i iskusstve, $3^{\text {rd }}$ edition. 1967, 457-466.

Pletnëv, VF. 1922b. Flengo. Dramaticheskiy epizod v 2-kh deystviyakh po rasskazu Lyus'ena Dekav. Moscow: Biblioteka Vserossiisk. Proletkul'ta.

Pletnëv, VF. 1923. Lena. Ocherk istorii Lenskikh sobytii (s prilozheniem). Moscow: Vserossiiskiy Proletkul't.

Pletnëv, VF. 1924a. Lena. (4 aprelya 1912). Kursk: Supplement to Kurskaya Pravda.

Pletnëv, VF. 1924b. Prav li t. Trotskiy? - Rechi o proletarskoy kul'ture. Moscow: Vserossiiskiy Proletkul't.

Pletnëv, VF. 1925. "Otkrytoe pis'mo v redaktsiyu zhurnala "Kino-nedelya", Kino-nedelya, (6): 9.

Protokoly Pervoi Vserossiyskoy Konferentsii Proletarskikh kul'turno-prosvetitel"nykh organizatsii 15-20 sentyabrya 1918.g. 1918. Moscow: Izd. Proletkul'ta.

Steinberg, MD. 2002. Proletarian Imagination. Self, Modernity, and the Sacred in Russia, 1910-1925. Ithica and London: Cornell University Press.

Taylor, R. (Editor) \& William Powell (Translator) 1995. Beyond the stars. The Memoirs of Sergei Eisenstein. London and Calcutta: BFI Publishing.

Taylor, R. (Editor and Translator), 2010. Sergei Eisenstein. Selected Works, Vol.1, Writings 1922-1934. London \& New York: I.B.Tauris, Ltd.

Tikka, P. 2009. "Tracing Tectology in Sergei Eisenstein's Holistic Thinking", in Oittinen, Vesa ed., Aleksandr Bogdanov Revisited, Helsinki: Aleksanteri Series, Nr.1, 211-234.

U istokov NOT - Zabytye diskussii i nerealizovannye idei 1990. Leningrad: Izdatel'stvo Leningradskogo Universiteta.

V.I. Lenin o literature i iskusstve 1967. Moscow: $3^{\text {rd }}$ edition, Izdatel'stvo Khudozhestvennaya literatura. Voprosy kul'tury pri diktature proletariata. Sbornik. 1925. Moscow: Gos.izdat.

Yakovlev, Ya. 1922. "O 'proletarskoy kul'ture' i Proletkul'te". Pravda, 24 \& 25 October and in Voprosy kul'tury pri diktature proletariata 1925, 21-45. 
Yakovlev, Ya. 1923. "Men'shevizm v Proletkul'tovskoy odezhde", Pravda 4 January .

Yampolskiy, M. 2009. "Ot Proletkul'ta k Platonu. Eizenshtein i proekt smyslovoy samoorganizatsii zhizni". Kinovedcheskie zapiski, Nr. 89. www.kinozapiski.ru/no/sendvalues/960.

Yurenev, RN. 1985. Sergey Eizenshteyn: Zamysly. Filmy. Metod. 1, 1898-1929. Moscow: Iskusstvo.

Zalambani, M. 1999. "Boris Arvatov. Théoricien du Productivisme". Cahiers du Monde russe, 40/3, 415-446.

\section{Authors information}

John Biggart MA, BLitt, PhD. is an independent scholar. He took his first two degrees in the University of Glasgow and his doctorate in the University of East Anglia, where he taught the history of Russia, of Poland, and of the Czechs and Slovaks. In 2000 he diversified into technical assistance in the Russian Federation, working with the Ministry of Finance and the Ministry of Health, mainly in the field of public finance reform. His current projects include: a) A Financial History of Bolshevism; b) The World View of Aleksandr Bogdanov; 3) Sergei Stepanovich Chakhotin and the Scientific Organization of Labour. His publications can be found at jbiggart.academia.edu/research

Oksana Bulgakowa, Professor emeritus of Film Studies at the Johannes Gutenberg University in Mayans. She has published several books on Russian and German cinema (Sergei Eisenstein: Three Utopias. Architectural drafts for a Film Theory, 1996; FEKS - The Factory of Eccentric Actors, 1997; The Adventures of Doctor Mabuse in the Country of Bolsheviks, 1995; The White Rectangle. Kazimir Malevitch on Film, 1997 (English Edition 2002); Sergej Eisenstein. A Biography. German Edition 1998; English edition 2003, Russian edition 2017; Factory of Gestures, Moscow 2005, 2021; Soviet Hearing Eye: Film and its Senses, Moscow 2010; Resonance-Space: The Voice and The Media, Berlin, 2012; Voice as the cultural Phenomenon, Moscow 2015; Things in Film: Silent monologue, Hidden memory, 2021), directed films (Stalin - a Mosfilmproduction, 1993; The Girl who kissed Stalin, SR, 1995; The Different Faces of Sergei Eisenstein, 1998), curated exhibits (film section of an exhibit Moscow - Berlin, Berlin - Moscow 1900-1950; Eisenstein's Mexican Drawings, Antwerp 2009)and developed multimedia projects (a website The Visual Universe of Sergei Eisenstein, Daniel Langlois-Foundation, Montreal, 2005; DVD "Factory of Gestures. On Body Language in Film", Stanford Humanities Lab, 2008; Sergei Eisenstein; My art in Life for Google Arts \&Culture, 2017). She taught at the Humboldt University and Free University, Berlin, Stanford, UC Berkeley and the International Film School in Cologne.

Ian Christie is a film and media historian, occasional critic, exhibition curator and broadcaster. A Fellow of the British Academy, he teaches at Birkbeck, University of London, and was Visiting Professor at Gresham College 2017-21. He recently co-edited The Eisenstein Universe, with Julia Vassilieva; and work on Robert Paul has produced a book, a graphic novel, and exhibitions. He is currently working on a book and exhibition about the early Soviet avant-garde in Petrograd, and the careers of Grigori Kozintsev and Leonid Trauberg.

\section{○ \\ OPEN ACCESS}

Copyright: @ 2021 The Author(s). This is an open-access article distributed under the terms of the CreativeCommons Attribution 4.0 International License (CC-BY 4.0), which permits unrestricted use, distribution, andreproduction in any medium, provided the original author and source are credited. See http://creativecommons.org/licenses/by/4.0/. 